\title{
»Becoming English«: Nationality, Terminology, and Changing Sides in the Late Middle Ages
}

\author{
Andrea Ruddick*
}

Late medieval English chronicles contain several puzzling references to the idea of people 'becoming English by changing allegiance, usually in the context of war. How does this fit in with the predominantly 'racial understanding of nationhood that permeated late-medieval English literary texts and official rhetoric, based on well-established ideas about birth, blood and heredity? These assumptions provided a powerfully persistent backdrop to late-medieval English writers' constructions of national identity and culture, which had an impact not only in literary spheres but also on government rhetoric and policy. Was it possible for a person to change nationality by changing sides? It is argued that these scattered references by certain chroniclers to 'becoming «nglish, French or Scottish refer not to an actual change in nationality as a legal and political status but act as a shorthand way of describing an anomalous change of political allegiance. Such instances of changing sides went against the grain of the political behaviour expected from a person born into a certain nationality but they did not change that nationality, which was associated with blood and birth. The essay goes on to examine the language of denization, by which foreigners were granted the legal rights and privileges of a native-born English person. From a close examination of the range of Latin vocabulary used in official documents, it is argued that even denization did not effect a change in the perceived nationality of the recipient, but only allowed for them to be treated as if they were English, in certain circumstances. Moreover, this new legal status did not automatically remove the alien social and cultural identity of recipients in the eyes of local political society, particularly at times of political tension such as the Glyn Dŵr revolt in Wales or outbreaks of war with France. By teasing out the implications of these puzzling uses of language and terminology, it is possible to refine and complicate our understanding of the intersection of ideas about race, subject-hood, allegiance, and nationality in both the texts and the politics of late medieval England.

Keywords: nationality; medieval England; English; race; ethnicity; national identity; war; denization; Welsh; allegiance; aliens; immigration

\footnotetext{
* Correspondence details: Dr Andrea Ruddick, Exeter College, Oxford, OX1 3DP. Email: andrea.ruddick@exeter.
} ox.ac.uk / andrearuddick.online@googlemail.com. 
This paper began life as a puzzle. When, in 1355, the Northumbrian knight Sir Thomas Gray was captured by the Scots and imprisoned in Edinburgh castle, he decided to make productive use of his captivity by beginning to write a chronicle, which became the Scalacronica. ${ }^{1}$ At one point in this account of the Anglo-Scottish wars, he used a surprising phrase. Describing how the earl of March changed sides in 1333, Gray wrote that the earl 'became English' (or, in his original French, deueint Engles). ${ }^{2}$ Why is this surprising? In late medieval England, much of the written evidence - literary, ecclesiastical and governmental - points to an understanding of national identity along the lines of what might today be described as an ressentialist model. That is, Englishness was most commonly assumed by contemporary writers to be something that a person was born with, rather than something that could change. ${ }^{3}$

Ethnographic discourse differed across time and space in medieval Europe in respect of the relative importance placed on the possible defining features of a people, such as descent, law, language, customs, and territory. ${ }^{4}$ Late medieval English identity certainly entailed a geo-political dimension. From at least the mid-thirteenth century, references to the English people in official rhetoric were increasingly closely associated with the kingdom of England and to the rule of the English king. ${ }^{5}$ However, a great deal of the language used to describe the English people also reflected what we might now call racial thinking. Birth was a dominant theme; both birthplace, usually within the kingdom of England, and birth to English parents. More than this, ideas about birth, blood, descent, and heritage were frequently (although not always) used to explain the different cultural characteristics of the English, their neighbours, and their enemies. ${ }^{6}$ Some historians, notably Robert Bartlett, have argued that from around the late-fourteenth century, there was a shift in European political thought from a flexible cultural definition of peoples in terms of laws, customs and language to a more rigidly biological and racial understanding of what constituted a people. ${ }^{7}$ With regard to medieval England, however, assumptions about the role of race and heredity in defining Englishness can be detected as early as the twelfth century in the work of chroniclers such as Henry of Huntingdon and William of Malmesbury. ${ }^{8}$ Even English chroniclers' acknowledgement of the hybrid nature of the English people, following multiple waves of invasion and settlement, reinforced this basically racial understanding of what defined a people, as the 'mixed background of the English was cited by chroniclers as a way to explain some of their character traits, such as instability and a propensity to regicide. ${ }^{9}$ Thus even perceived changes to national character were explained using a racial model, and English identity was generally assumed to be an essential, immutable fact, fixed at birth rather than something

\footnotetext{
Thomas Gray, Scalacronica, ed. King.

Thomas Gray, Scalacronica, ed. King, 116-117.

An argument I have developed at length elsewhere, e.g. Ruddick, English Identity.

Bartlett, Medieval and Modern Concepts of Race, 47-48; Bartlett, Making of Europe, 197-198; Pohl, Strategies of Distinction, 17-18; Reynolds, Kingdoms and Communities, 257.

Ruddick, English Identity, 183-204.

Ruddick, English Identity, 132-155.

Bartlett, Making of Europe, 197-8, 236-241; Kim, Aliens in Medieval Law, 9-15.

Gillingham, English in the Twelfth Century.

9 Thomas Gray, Scalacronica, ed. King, 95-97; Brut, ed. Brie, 220; Polychronicon, II, ed. Babington and Lumby, 164166; Ruddick, English Identity, 140-141.
} 
that could change. This is not to say that all people in medieval England thought in the same way about being English in every context; simply that most writing about national identity at the time was underpinned by these assumptions. All of which makes Sir Thomas Gray's comment somewhat puzzling on first inspection.

Their essentialist content notwithstanding, these expressions and constructions of national sentiment in medieval chronicles, sermons, poetry and official rhetoric primarily drew on and appealed to subjective ideas about belonging culturally, historically, and sometimes racially to the English people. From the late fourteenth century, however, a more objective official definition of 'nationality، as a legal status was also emerging. Initially, English nationality law developed in a fairly ad hoc way, often in response to changing social or political circumstances. In the mid-fourteenth century, for example, in the midst of military campaigns in France, parliament issued legislation to confirm the English nationality of children born to English parents overseas, including two royal princes..$^{10}$ As different circumstances and questions arose, the official definition of English nationality was gradually refined. If anything, however, special provision in these exceptional cases only served to emphasise that the norm was for English nationality to be defined by birth in England, to English parents. ${ }^{11}$ What also gradually emerged over the later middle ages was the idea of certain rights and privileges associated with legal English nationality. This included the right to trade freely, to use English courts, and the ability to buy and sell property and pass it on to one's heirs. These privileges became more clearly defined by virtue of occasionally being granted to foreigners, through a process which became known as denization. By the end of the fourteenth century, the acquisition of these rights by foreigners had also become associated with a more formal change of allegiance to the English crown. ${ }^{12}$ Consequently, what had emerged by the end of the fourteenth century was an increasingly well-defined package of these rights and privileges, which English people automatically acquired by birth but which could also be granted to foreigners in special circumstances. Whether this made them 'English or not, however, is open to question.

The situation was further complicated in medieval England by the fact that the kingdom of England was not the only political structure through which power was mediated by the English crown. As is well known, the king of England also claimed dominion over a number of other lands, as, for example, duke of Normandy (until 1204), lord of Ireland (from 1171), overlord of Scotland (expressed more assertively from 1296), lord of the Channel Islands, and duke of Aquitaine (from 1154), a title he retained even after his claim to the French throne in 1337. Consequently, although all English people were subjects of the king of England, not all subjects of the king of England were English. This created an ambiguous relationship in English official rhetoric between specifically English national identity and the broader notion of political allegiance - or, as I have called it elsewhere, allegiant identity - which did not always coincide. ${ }^{13}$ Once again, however, these anomalous situations only served to reinforce the underlying assumption that English nationality was something a person was born with, and which remained unchanged, even if their allegiance shifted.

10 PROME, Edward III: Parliament of April 1343, item 19, ed. Ormrod; PROME, Edward III: Parliament of February 1351, item 41, ed. Ormrod; Statutes of the Realm, I, ed. Raithby, 310; Griffiths, English Realm and Dominions, 89, 93-95. 
What, then, are we to make of comments such as Thomas Gray's about the earl of March, which seem to suggest that a person had 'become English ‘? Cases of denization, too, are sometimes portrayed by historians as if they had effected a real change in the recipient's nationality. Could a person really 'become English ' in the late middle ages? The rest of this paper explores some instances where medieval writers - and modern historians - have used the language of 'becoming English in an attempt to answer to this question, looking first at some further occurrences of 'becoming English` in literary contexts before turning to an official perspective and examining the language of denization. By scrutinising these examples, what started out as one historian's growing collection of puzzling case-studies can help to refine our understanding of the intersection of ideas about race, subject-hood, allegiance, and nationality in late medieval England.

First, then, some more literary references to 'becoming English'. These invariably come in the context of a person or group changing sides during the Hundred Years War against France and the related Anglo-Scottish conflict. For example, in a newsletter sent home from France by Henry of Lancaster, the earl of Derby, in 1346, Lancaster recorded the capture of the French town of St Jean d'Angély by the English, as a result of which 'those of the town swore an oath to us and became English $\times{ }^{14}$ Thomas Gray also used similar phrases elsewhere in Scalacronica to describe shifts of allegiance and, in one case, the opposite: Robert de Bruce's nephew Thomas Randolph, the future earl of Moray, was captured at the battle of Methven in 1306 but released and 'remained English' (demora Engles), at least until his recapture by the Scots in $1308 .{ }^{15}$ Another example is provided by the case of Peter Libaud, the constable of Edinburgh castle at the time of its siege in 1314, who had reportedly 'become Scottish in the allegiance (a la foy) of Robert de Brucer. ${ }^{16}$ In these examples, as in the case of the earl of March, it seems fairly clear that these writers did not mean that those who switched sides had literally changed their nationality of birth. What is much more likely is that the language of 'becoming' English or Scottish acted as a shorthand for a shift in allegiance. The chosen form of this shorthand reflected the contemporary assumption that opposing sides in a conflict were largely made up of two clearly defined national groups. This use of the phrase is particularly evident in Gray's descriptions of Peter Libaud, whom he variously described as 'English' or 'Scottish', depending on his allegiance at the time, until Libaud's eventual execution for treason because Robert Bruce suspected that Libaud 'had always been English at heart. ${ }^{17}$ These shifts in classification occur despite the fact that, as Gray and every other chronicler who mentions him make clear, Libaud was in fact neither English nor Scottish by birth, but Gascon. ${ }^{18}$ In other words, the term 'English ' here was an abbreviated reference to being on the king of England's side, which reinforced the idea of a world in which political loyalties usually fell along national lines, even though the writers were well aware that reality was often more complex. (English soldiers who had captured the French commander Lewis de Harcourt in the Black Prince's 1359-1360 campaign in Normandy released him and >deueint Fraunceis`).

16 Thomas Gray, Scalacronica, ed. King, 73. For further biographical details of Peter Libaud, see Ruddick, Gascony and the Limits, 81 .

17 Thomas Gray, Scalacronica, ed. King, 73.

18 E.g. Galbraith, Extracts From Historia Aurea, 210; Vita Edwardi Secundi, ed. Denholm-Young, 48; John Barbour, Bruce, ed. Duncan, 376-379, 398-399. 
This is not unlike the way in which, elsewhere in chronicles, writers repeatedly demonstrated their understanding that the 'English' army was made up of a mixture of nationalities, which included not only Gascon subjects but also Welsh archers and foreign mercenaries. ${ }^{19}$ Nonetheless, chroniclers always reverted to the simple convention of describing the two sides as 'the English' and 'the French' or 'the Scots' when it came to composing battle accounts..$^{20}$ This figurative sense of 'becoming English` to mean a change of allegiance to the English side is also reinforced by a more light-hearted use of the phrase by Henry Knighton, the Augustinian canon and chronicler, in the late fourteenth century. Knighton repeated the well-known political joke about the Anglo-French conflict that 'the pope has become French and Jesus has become English! ${ }^{21}$ In other words, the language of 'becoming English - or French or Scottish - was used in these contexts to signal allegiance, and not to express a change in a person's nationality or, indeed, in their ethno-cultural self-identification. Nationality, in the sense of a legal status assigned by birthplace and parentage, remained a separate category from allegiance in chroniclers' minds even if the latter might sometimes be given a 'national label as a convenient shorthand.

In fact, the language of 'becoming English` is relatively rare in English sources, aside from the few chronicles and newsletter cited above. However, it does crop up in some contemporary French governmental sources, where it is used in a very similar way. One such example is the case of Hannequin de Bos, a Frenchman who was captured by the English in 1385 while on an expedition to Scotland. According to the French judicial records, de Bos was persuaded by his English captors to 'become English and to take the side of the English' (d'estre Englez et de tenir la partie de Engles) by becoming a spy. He was evidently not a very good spy, however, as we know about his case from the records of his confession before his execution by the French in $1390 .{ }^{22}$ The language of becoming English was similarly used to denote a change of allegiance in a case that was heard by the Paris Parlement in 1437. In this case, the Parlement blocked the marriage of a young Frenchwoman called Jeanette Roland to an English soldier she had met during the occupation of the city. The marriage was forbidden by the Parlement on the grounds that they could not allow Jeanette to 'become English' (devenir anglesche) by marrying an English soldier during the war. ${ }^{23}$ Was marriage to an Englishman enough to change this woman's nationality? In England at the time, marriage to an English person in itself did not change an alien spouse's nationality, although it might bring certain legal or financial protections. ${ }^{24}$ Alien wives were exempt from the alien subsidies of the 1440 , for example, but were still regarded as aliens and thus in need of exemption in the first place. In this French case, what seems to have triggered the use of the phrase 'become English ' was not the marriage itself but its wartime context, which would have involved allowing a French subject to leave one kingdom and ally herself to another.

21 Knighton's Chronicle, ed. Martin, 150 [my translation]; Barnie, War in Medieval Society, 12; McKenna, How God Became an Englishman, 30.

22 Alban and Allmand, Spies and Spying, 84.

23 Bossuat, L’idée de nation, 55. I am grateful to Dr Craig Taylor for drawing my attention to this reference.

24 Ruddick, Immigrants and Inter-Marriage. 
These examples are few and far between, spanning a century-long time range, and coming from opposite sides of the Channel and several different genres of writing. Nevertheless, it is striking that the language of 'becoming English` seems to have been used by French authorities in the above cases in much the same way that it was used by fourteenth-century English writers. Given that the comparative rarity of the phrase in English chronicles, it is notable that both Sir Thomas Gray and Henry of Lancaster were members of the aristocratic military classes who participated in Edward III's wars. Henry of Lancaster spent much of his adult life serving Edward III overseas and although Gray spent the greater part of his career on the Anglo-Scottish borders, he also served in Flanders in 1338-40 and in France in 1359. ${ }^{25}$ It is possible to speculate that the vocabulary of 'becoming English/French' may have been more common in French governmental or legal contexts and that it may, perhaps, have been picked up by these particular English writers precisely because of their francophone military context. Such conjecture aside, this recurrent turn of phrase in a variety of sources associated with the Hundred Years War highlights the close yet politically fraught relationship between nationality, allegiance, and expectations of political behaviour in the context of a dynastic war that was being framed as a conflict between two national sides. ${ }^{26}$ In this context, the rhetorical device of 'becoming English' reflects the need to describe and explain anomalous political behaviour which did not match normative expectations created by nationality labels.

So far, there is nothing to suggest that the vocabulary of 'becoming English' was anything other than a shorthand way to describe changing sides, rather than changing nationality. When we find similar vocabulary applied to cases of denization, however, the relationship between ideas about nationality, race, and political allegiance can seem less straightforward. Most denizations were granted to resident aliens in England in the context of exemption from taxation or wartime expulsion orders. One more unusual case recorded on the Parliament Rolls of 1439 concerned not a resident alien but one William ap Gwilym ap Griffith, a man who was described as 'English on his mother's side... and Welsh on his father's sider. ${ }^{27}$ William petitioned the English parliament that they might 'make the said William an Englishman' (de faire le dit William Engloys), on the basis of his English mother (Joan, the daughter of Sir William Stanley) and his long history of allegiance to the English king, noting that 'his pleasure in times of Welsh rebellion and in all later times for his whole life was faithful allegiance to our lord the king and to his noble progenitors ${ }^{28}{ }^{28}$ The features of William's case reveal various ideas about nationhood and subject-hood; the role of birth and parentage takes centre-stage, yet importance is also placed on loyalty to the king. However, personal feelings of attachment to the English crown were not the prime motivation behind this petition. Although it is possible that his anglicised forename represented a conscious preference for an English self-identification (although equally it could have been a way of playing up his English ancestry for an English audience, or a designation chosen by the parliamentary scribe), this petition was not primarily a matter of personal sentiment. The reason for William's request was specific and practical: he wanted to be declared legally English in order to escape the restrictions on land tenure and office-holding that had been imposed 
on the Welsh since the Glyn Dŵr revolt in Henry IV's reign. William asked to be able to buy lands in England and Wales and pass them onto his heirs, to plead and be impleaded in English courts, to hold office, and to enjoy all other liberties of faithful Englishmen. Being 'made an Englishman` in this context implied access to the full set of legal rights and privileges associated with English nationality by this point.

In the event, William was only partly successful. Although he was granted the right to buy and pass on land and to use English courts, he was still banned from holding office, and the whole grant was only made on the condition that he did not marry a Welsh woman. It seems that his Welsh blood still made him suspect in a politically sensitive context such as officeholding, and this suspicion would be reinforced if he married a Welsh wife and produced children who had more Welsh blood than he did. The ruling also reflects the wider climate of Anglo-Welsh political tensions in the early fifteenth century; Englishmen with Welsh wives had been banned from holding office in Wales since the Glyn Dŵr revolt. Although the need for laws regulating inter-marriage in itself suggests that not all Englishmen viewed relations with their Welsh neighbours in quite so hostile a light as the English government, there were renewed petitions for this ruling to be enforced in the parliaments of 1431 and $1433 .{ }^{29}$ As in the case of Jeanette Roland, noted above, marriage to a foreigner did not effect a legal change in nationality (for a partner of either gender), but in certain contexts it constituted a highly political act which rendered the person 'marrying out` an object of suspicion.

The issue of restrictions on office-holding for men with Welsh blood or Welsh wives came up again in 1445, with the added request that no more Welshmen 'shall be made denizen or English', whether they were 'Welshmen of whole blood or half blood on the father's side. ${ }^{30}$ The reason for this request, the petition in 1445 explained, was fear that if the Welsh were made equal to Englishmen in Wales through denization, they might use their new powers to take revenge on the English, 'for whom they have great hatred in heart, countenance and word... on the grounds of the slaughter and destruction of their rebel ancestors in the time of rebellion.$^{31}$ The extent to which such fears were well-founded, or even representative of genuine concerns on the part of the English in Wales, is less relevant here than the fact that it was in partly racial terms that the argument was framed. Even if men like William ap Gwilym were able to separate the legal and political concept of becoming a denizen, with the same privileges as a full Englishman, from racially-charged views of their Welsh blood, the two were not easily separated in wider political culture, especially in the climate of official paranoia that followed the Glyn Dŵr revolt. This is highlighted by William's second attempt at getting permission to hold office in $1442 .{ }^{32}$ This time, he appears to have tried to beef up his claims to English nationality by making his father sound less Welsh. His English-language petition now described him as 'Englissh of his moderside... and aparte Englissh on his fadersider. He also talked up his father's faithfulness to Henry IV during the Welsh rebellion. And, this time, he had more success; he was granted permission to hold office for life or for a fixed term, although his request to hold hereditary office was referred..$^{33}$

PROME, Henry VI: Parliament of January 1431, item 32, ed. Curry; PROME, Henry VI: Parliament of July 1433 , items 29-30, ed. Curry. See also Statutes of the Realm, II, 140-141.

30 PROME, Henry VI: Parliament of February 1445, item 26, ed. Curry. 
To be 'made English ' in this context was evidently different from the literary formula of 'becoming English to denote a change of sides - but it still did not amount to a wholesale change of 'nationality‘. William ap Gwilym was seeking to be made legally English in order to remove the particular legal disadvantages of his Welsh ancestry, but he was only partly successful on account of his mixed ancestry. Indeed, not only did the possession of certain rights and privileges of English nationality not 'maker William English, but his Welsh heritage debarred him from access even to the same full set of legal rights as a denizen who originated from elsewhere. It also seems unlikely that William ap Gwilym felt any more or less 'English ' than he had before, simply as a result of acquiring the right to hold office; his petition was evidently motivated more by pragmatism than by national sentiment. As we can see from official attitudes towards the Welsh in this period, national identity in the eyes of English political society remained a matter of birth and blood rather than simply a choice of allegiance and a matter of acquiring certain legal rights - even when the need to accommodate anomalous cases like William ap Gwilym's presented an obvious challenge to this conceptual framework.

Looking more broadly at some further examples of denization may also shed light on the conundrum of whether a person could officially 'become English in this period. There has been a recent renewal of interest in denization, partly as a result of the England's Immigrants 1330-1550 project on resident aliens in medieval England, which has built up a database of foreigners living in the kingdom using records including letters of denization. ${ }^{34}$ In particular, Bart Lambert and Mark Ormrod's recent work has provided a much more coherent narrative of how and why denization emerged in English society during the late middle ages. ${ }^{35}$ Should denization be equated with a change of nationality, however? I would argue that we need to be very careful about the terminology we use to describe it, and particularly the dangers of conflating denization with nationality.

To take a well-known early example that is often cited by historians, in August 1295, Edward I declared that Elias Daubenay, who was originally from Brittany, was to be treated as an Englishman (ut Anglicus) in the royal courts, as a mark of special royal favour. ${ }^{36}$ The document stated that Daubenay was:

to be heard as an Englishman (ut Anglicus) in all English royal courts, and that he is to be answered as an Englishman (ut Anglico), and that he is not to be rejected by the exception that he is an alien and born overseas (alienigena est et natus in partibus transmarinis), because the lord king holds the same Ellis to be a pure Englishman (quia dominus rex ipsum Elyam Anglcium purum tenet), and wishes him to be so considered and held by others in his realm. ${ }^{37}$

34 England's Immigrants, 1330-1550: Resident Aliens in the Late Middle Ages, an AHRC-funded project led by Professor W. M. Ormrod, as a collaboration between the University of York, The National Archives and the Humanities Research Institute, University of Sheffield. For the database, see www.englandsimmigrants.com (retrieved on 20 April, 2017).

35 Ormrod and Lambert, Friendly Foreigners, 1-24.

36 E.g. Beardwood, Mercantile Antecedants, 66; Griffiths, English Realm and Dominions, 89; Kim, Aliens in Medieval Law, 119-120; Ormrod and Lambert, Friendly Foreigners, 2; Parry, British Nationality Law, 18; Pollock and Maitland, History of English Law, 463-464.

37 PROME, Edward I: Roll 10, item 6, ed. Brand. 
Taken alone, the statement that the king regarded Daubenay as a 'pure Englishman` might appear to suggest that Daubenay had officially changed nationality and become English. Certainly, this is how the case is often written up by legal historians looking for precursors to modern forms of naturalization. However, the repeated use of the Latin word $u t$, 'as', in the surrounding document may suggest that this was not the case - the words also admit the possibility that what Daubenay had been granted was the right to be treated as if he were an Englishman in one particular context, the royal courts. If anything, the insistence of the grant that Daubenay was to be treated like a 'pure Englishman' despite his birth overseas reinforces the centrality of birthplace as the normative criterion for English nationality.

I want to suggest that Latin words like $u t$ could be quite telling when we examine letters of denization, which became increasingly standardised over the next two centuries. ${ }^{38}$ Repeatedly, in these documents, people were granted the right to be treated 'as if ‘ they were English, through the use of words like ut, velut, sicut, and, most frequently, tamquam Anglicus - all of which to a varying degree could carry the sense of the recipient being treated 'as if ', 'just as if‘, 'just as`, 'just like`, or 'as though` they were English, particularly the most commonly used, tamquam. ${ }^{39}$ These tell-tale little phrases may make a difference to how we understand the relationship of denization to nationality, because they suggest that denization did not actually make a person English in the eyes of the English Chancery, but simply allowed them to be treated 'as if ' they were in certain limited contexts, creating a legal fiction of English nationality. ${ }^{40}$ Even after denization regularly began to feature a more formal transfer of allegiance to the crown by swearing an oath of fealty from the 1370 s, perhaps we should hesitate to describe this in terms of a formal change of nationality, at least in cases where a recipient's new status was prefixed with equivocal language such as tanquam or sicut. In 1397, for example, when the German merchant John Swart was granted the right to hold property, to pass it on to his heirs, and to use English courts, the record on the Patent Rolls stated twice that he was to be treated rjust as if he were one of our true and faithful lieges born within the kingdom of England (sicut unus de veris et fidelibus ligeis nostris infra regnum nostrum Anglie oriundus) $\times .^{41}$ The same kind of language can be seen in the wartime grants of corporate denization obtained by alien priories to avoid financial exploitation by the English crown as a result of their suspicious connections with their French mother-houses. In November 1414, when Henry V ordered the seizure of all alien priories in England, the prior and convent of St Neots, originally a daughter-house of the French abbey of Bec, reminded the king that his father, Henry IV, had granted their priory denization in 1409. The terms of this grant were that the prior and convent should be considered, regarded and treated as if denizens and English (tanquam indigene et Anglici), and should exist in the same status as the true English born within our realm of England do (sicut sunt veri Anglici infra regnum nostrum Anglie nati), in perpetuity. ${ }^{42}$ This kind of language implies two things: first, that denization had

38 See examples transcribed in Beardwood, Mercantile Antecedants, 74-76; and examples cited Ormrod and Lambert, Friendly Foreigners, 18-22.

39 E.g. Lewis and Short, Latin Dictionary.

40 For similar arguments about the use of tanquam to draw an analogy between the legal status of Jews and that of serfs in particular contexts, see Jordan, Jew and Serf, 248-254; Langmuir, Toward a Definition, 176-188. I am grateful to the anonymous reader of a draft of this paper for bringing this parallel to my attention.

41 Calendar of Patent Rolls 1396-1399, 84, cited in Beardwood, Mercantile Antecedants, 75.

42 PROME, Henry V: Parliament of November 1414, item 25, ed. Given-Wilson. 
given the likes of the St Neots monks and John Swart the right to be treated 'as if ' they were native English denizens, but secondly that they were still not, in fact, 'true English ' because they had not been born in the kingdom of England.

Of course, the diplomatic of the English Chancery was not completely stable in this period, its formulaic nature notwithstanding, and nor was the use and intended meaning of the words themselves in official rhetoric, let alone how they may have been understood by wider political society. The ambiguity of these words may even have been part of their usefulness in this context. Nonetheless, the language used in these documents merits close scrutiny as evidence of how the English royal government attempted to grapple with the variegated and evolving legal, fiscal and political distinctions between English people, other subjects of the king of England, and friendly aliens living in the kingdom of England in relation to established concepts of nationhood.

At the end of the day, this distinction may not have mattered much in purely legal terms - actually to have 'becomer English or simply to have the right to be treated ras if English in a law court may not have looked very different in practice. But in another, important, sense, the recipients of these documents had not 'become Englishr. Even if they were legally English (or as good as), a switch of allegiance or a grant of denization did not make them English in the sense of changing the national identity of their birth, with all its attendant cultural, linguistic and social expectations in the eyes of political society, regardless of the financial and legal privileges they had acquired. As the case of William ap Gwilym shows, legal privileges did not necessarily protect a person with alien blood from ethnic hostility and suspicion when the political temperature changed. This is borne out by the experiences of resident aliens who lived in the kingdom of England in the fourteenth and fifteenth centuries. Some of these people had lived in England for decades, had married an English spouse, and were well integrated into their local community, but they were still readily identified as foreigners by the authorities (and by members of the local population who provided those authorities with information) when political circumstances changed and punitive measures against resident aliens were imposed. ${ }^{43}$ Whether during the confiscations of French property in 1294,1324 and 1337 , the expulsion orders of $1377-1378$, or the alien subsidy assessments of the 1440s, people knew who the foreigners were in their community; indeed, this was often the point at which aliens sought denization, in order to acquire legal protection from the consequences of their foreign origins. Tellingly, even Elias Daubenay, declared a 'pure Englishman in August 1295, had his lands temporarily seized by the sheriff of Lincoln a few months later as a result of the war with France. ${ }^{44}$ The sheriff was soon ordered to return Elias' lands to him, but this episode and others like it suggest there was some gap between the acquisition of some of the legal rights and privileges associated with English nationality and a wholesale and widely accepted change of national identity.

So, could people in late medieval England 'becomer English? From side-switching soldiers in the Hundred Years War to resident aliens seeking the protection and legal privileges associated with English nationality, I would argue not. Even if the boundaries between categories of nationality and allegiance in the king of England's lands were complex, and possibly converging, by the end of the middle ages, they remained two very different things 
in the political culture of late-medieval England. Changes in allegiance, whether described as 'becoming English in the context of war against France and Scotland or expressed through the increasingly formal processes of denization that developed back at home, could not erase the underlying assumption that nationality was something a person was born with. Contemporary beliefs about blood, descent, and race provided a powerful backdrop to official and literary constructions of national identity in England between the late thirteenth and early fifteenth centuries. These ideas infused both literary and official expressions of Englishness in the late middle ages as the royal government interacted with the changing political circumstances that required the development of a more tightly-defined English nationality law. Of course, there is no reason to suppose that medieval English society, and the individuals and groups within it, held any more coherent or consistent a view of what it meant to be English than people in any other period of history. Historians have long been wary of assuming that words or symbols meant the same thing to everyone, and this danger is particularly clear where the evidence is sporadic and covers a long period of time. Individual people might play around with these definitions, or adopt a certain flexibility towards the labels they gave themselves in different contexts. Moreover, questions of race, national identity and political allegiance were unlikely to have been overriding concerns at the forefront of most people's minds, most of the time. Nonetheless, in certain political contexts the question of a person's nationality became salient, and this generated the need for a vocabulary to describe anomalous situations in which race, nationality, allegiance, and associated expected political behaviour did not match up. The need to describe, negotiate, and contest the spaces (whether perceived by others or experienced personally) between a person's changing legal and political status and their past and present cultural identities is not a problem unique to northern Europe in the middle ages. In this particular historical and geographical context, however, the language of 'becoming English` offered one possible solution to this conundrum. 


\section{References}

\section{Primary Sources}

Barbour, John, The Bruce, ed. Archibald A. M. Duncan (Edinburgh, 1997).

The Brut or the Chronicles of England, ed. Frederick W. D. Brie, 2 vols. (London, 1906-1908).

Calendar of Patent Rolls, Richard II, Volume VI, 1396-1399 (London, 1909).

Calendar of Patent Rolls, Henry VI, Volume IV, 1441-1446 (London, 1908).

Gray, Thomas, Scalacronica, 1272-1363, ed. Andy King (Woodbridge, 2005).

Knighton's Chronicle, 1337-1396, ed. and trans. Geoffrey H. Martin (Oxford, 1995).

Parliament Rolls of Medieval England, 1275-1504 [PROME], eds. Christopher Given-Wilson, Paul Brand, Seymour Phillips, Mark Ormrod, Geofffrey Martin, Anne Curry and Rosemary Horrox [online version] (Leicester, 2005). Retrieved on 19 February 2017: ezproxy-prd.bodleian.ox.ac.uk:2998/PROME.

Parliament Rolls of Medieval England, 1275-1504 [PROME], Vol. 2: Edward I, 1294-1307, ed. Paul Brand (Woodbridge, 2005).

Polychronicon Ranulphi Higden Monachi Cestrensis, ed. Churchill Babington and Joseph R. Lumby, Rolls Series 41, 8 vols. (London, 1865-86).

Robertus de Avesbury, De Gestis Mirabilus Regis Edwardi Tertii, ed. Edward M. Thompson, Rolls Series 93 (London, 1889).

Statutes of the Realm, ed. John Raithby, 11 vols. (London, 1810-1828).

Vita Edwardi Secundi, Monachi Cuiusdam Malmesberiensis, ed. and trans. Noel Denholm-Young (London, 1957).

\section{Secondary Literature}

Alban, J. R. and Allmand, Christopher, Spies and Spying in the Fourteenth Century, in: Christopher Allmand (ed.), War, Literature and Politics in the Late Middle Ages (Liverpool, 1976) 73-101.

Barnie, John, War in Medieval Society: Social Values and the Hundred Years War, 1337-99 (London, 1974).

Bartlett, Robert, Medieval and Modern Concepts of Race and Ethnicity, Journal of Medieval and Early Modern Studies 31 (2001) 39-56.

Bartlett, Robert, Making of Europe: Conquest, Colonization and Cultural Changes, 950-1350 (London, 1993).

Beardwood, Alice, Mercantile Antecedants of English Naturalization Laws, Medievalia et $\mathrm{Hu}$ manistica 16 (1964) 64-76.

Bossuat, André, L’idée de nation et la jurisprudence du Parlement de Paris au XVe siècle, Revue Historique 204/1 (1950) 54-61.

Curry, Anne, The Hundred Years War (2nd edition) (Basingstoke, 2003).

Galbraith, Vivian H., Extracts from Historia Aurea and a French »Brut«(1317-1347), English Historical Review 43 (1928) 203-17.

Gillingham, John, The English in the Twelfth Century: Imperialism, National Identity and Political Values (Woodbridge, 2000).

Griffiths, Ralph A., The English Realm and Dominions and the King's Subjects in the Later Middle Ages, in: John G. Rowe (ed.), Aspects of Late Medieval Government and Society: Essays Presented to J. R. Lander (Toronto, 1986) 83-99. 
Jordan, William Chester, Jew and Serf in Medieval France Revisited, in: Arnold E. Franklin, Roxani E. Margariti, Marina Rustow and Uriel Simonsohn (eds.), Jews, Christians and Muslims in Medieval and Early Modern Times. A Festschrift in Honor of Mark R. Cohen (Leiden, 2014).

Kim, Keechang, Aliens in Medieval Law: the Origns of Modern Citizenship (Cambridge, 2000).

Langmuir, Gavin I., Toward a Definition of Antisemitism (California, 1990).

Lewis, Charlton. T. and Short, Charles (eds.), A Latin Dictionary (Oxford, 1879).

McKenna, John W., How God Became an Englishman, in: D. J. Guth and John W. McKenna (eds.), Tudor Rule and Revolution: Essays for G. R. Elton from his American Friends (Cambridge, 1982) 25-43.

Ormrod, Mark and Lambert, Bart, Friendly Foreigners: International Warfare, Resident Aliens and the Early History of Denization in England, c. 1250-c. 1400, English Historical Review 130 (2015) 1-24.

Parry, Clive, British Nationality Law and the History of Naturalisation (Milan, 1954). Retrieved on 19 February 2017: www.uniset.ca/naty/parry.htm.

Pohl, Walter (ed.), Strategies of Distinction: the Construction of Ethnic Communities, 300-800 (Leiden, 1998).

Pollock, Frederick and Maitland, Frederic W., A History of English Law before the Time of Edward I, vol. 1 (Cambridge, 1898).

Prestwich, Michael, War, Politics and Finance under Edward I (London, 1972).

Reynolds, Susan, Kingdoms and Communities in Western Europe (Oxford, 1984).

Ruddick, Andrea, Gascony and the Limits of Medieval British Isles History, in: Brendan Smith (ed.), Ireland and the English World in the Late Middle Ages (Basingstoke, 2009) 68-88.

Ruddick, Andrea, English Identity and Political Culture in the Fourteenth Century (Cambridge, 2013).

Ruddick, Andrea, Immigrants and Inter-Marriage in Late Medieval England, in: W. Mark Ormrod, Nicola F. McDonald and Craig Taylor (eds.), Resident Aliens in Later Medieval England (Turnhout, 2017) forthcoming. 